\title{
Effect of temperature on development and reproduction in Gastrophysa viridula (Coleoptera: Chrysomelidae)
}

\author{
AloIs HONEK ${ }^{1}$, VOJTECH JAROSIK ${ }^{2}$ and ZDENKA MARTINKOVA ${ }^{1}$ \\ ${ }^{1}$ Research Institute of Crop Production, Drnovská 507, CZ 16106 Praha 6 - Ruzyně, Czech Republic; e-mail: honek@vurv.cz \\ ${ }^{2}$ Department of Zoology, Charles University, Viničná 7, 12844 Prague 2, Czech Republic; e-mail: jarosik@mbox.cesnet.cz
}

Key words. Gastrophysa, Coleoptera, Chrysomelidae, Rumex, temperature, development, growth, reproduction, fecundity, rate isomorphy

\begin{abstract}
The duration of development, reproduction and longevity of Gastrophysa viridula (DeGeer) was measured at constant temperatures and a long day photoperiod. At $18,21.5,25$, and $28^{\circ} \mathrm{C}$ the average duration of development of the egg, larval and pupal stages and total development time $(28.2,21.6,16.1,15.0$ days) decreased with temperature but the proportion of time spent in the egg, larval and pupal stages did not significantly change with temperature. Total development required 304.6 day degrees above the lower development threshold of $7.1^{\circ} \mathrm{C}$. Pre-adult mortality and the rate of oviposition increased, and the duration of oviposition decreased with increasing temperature. Net reproduction rate $\mathrm{R}_{0}$ decreased (from 157 female eggs at $18^{\circ} \mathrm{C}$ to 75 female eggs at $28^{\circ} \mathrm{C}$ ) and mean generation time $\mathrm{T}$ also decreased (from 45.5 days at $18^{\circ} \mathrm{C}$ to 24.1 days at $28^{\circ} \mathrm{C}$ ) with increasing temperature. The intrinsic rate of population increase $r_{m}$ increased with temperature (from 0.111 at $18^{\circ} \mathrm{C}$ to 0.179 at $28^{\circ} \mathrm{C}$ ). On a physiological time scale the average generation time $\mathrm{T}$ was 496 day degrees.
\end{abstract}

\section{INTRODUCTION}

The performance of an insect species depends on many factors including temperature, which affects the rate of development, reproduction and ageing. Consequently, when food, photoperiod, population density and other factors are kept constant, temperature becomes the major determinant of species performance. Knowledge of the development rate, reproduction and mortality at a range of constant temperatures allows the construction of life tables and reveals the effect of temperature on species performance. Such life tables exist for many phytophagous Coleoptera including several species of Chrysomelidae (Wan \& Wang, 1990; Bassyouny \& Maareg, 1992; Bhumannavar et al., 1998; de Pecchioni et al., 2000).

One species that remained to be investigated is the herbivore Gastrophysa viridula (DeGeer) (Coleoptera: Chrysomelidae). This originally alpine species probably has spread to central Europe within the past 100 years (Renner, 1970). Although $G$. viridula may eat several Polygonaceae species (Chevin, 1968; Smith \& Whittaker, 1980a) including Acetosa pratensis Miller (Kovalenkov \& Stolyarov, 2000), Reynoutria spp. (Zimmermann \& Topp, 1991), Rheum spp. (Neubauer et al., 1979; Guile, 1984) and Polygonum aviculare L. (Bulcke et al., 1994), broadleaved dock Rumex obtusifolius L. followed by curled dock R. crispus L. (Polygonaceae) are the preferred host plants (Hatcher et al., 1994a). G. viridula is thus a potential biocontrol agent of dock (Swatonek, 1972; Barbattini et al., 1986; Hatcher et al., 1994b; 1997; Hatcher, 1996; Hann \& Kromp, 2001). In central and western Europe the species may have two to three generations per year but individual growth and population dynamics of $G$. viridula depends on host plant quality (Engel, 1956; Renner, 1970; Smith \& Whittaker, 1980a, b; Cottam et al., 1986).
Despite the practical importance of $G$. viridula little is known about the effect of temperature on this species. This information is important because development and reproduction occur throughout the season, under a wide range of thermal conditions. In addition, data on the effect of temperature on development may be tested for "rate isomorphy" (Jarosik et al., 2002). This paper presents the results on development time, reproduction and longevity of $G$. viridula reared at four constant temperatures. The data on development duration enabled calculation of thermal constants, lower development threshold, the sum of effective temperatures, and the testing for "rate isomorphy" (Jarosik et al., 2002). The data on adult oviposition and longevity were used to construct life tables.

\section{MATERIAL AND METHODS}

Rearing. The stock population of $G$. viridula was collected from a natural stand of $R$. obtusifolius on May 20, 2001 at Praha-Ruzyne, Czech Republic $\left(50^{\circ} 06^{\prime} \mathrm{N} 14^{\circ} 16^{\prime} \mathrm{E}\right)$. The adults were divided into five groups of 10 females and 5 males. Each group was placed in a $200 \mathrm{ml}$ plastic cup and supplied with fresh $R$. obtusifolius leaves collected from the field. The leaves had apparently a similar quality throughout the experiment (May 20 - July 20) as late on they were the new leaves produced by plants from which above ground parts were removed on June 10 and July 5 . The leaves were replaced at 6 or $12 \mathrm{~h}$ intervals. Adults were kept at $22^{\circ} \mathrm{C}$ and a natural photoperiod.

Egg development. The eggs were removed every six hours. Pieces of leaf with attached egg batches were cut from the leaves, the number of eggs counted and each leaf piece placed in a $18 \times 65 \mathrm{~mm}$ glass tube covered with a plastic lid, which permitted ventilation. A small piece of moist cotton wool was added to maintain high air humidity. The tubes were kept at 18 $\pm 0.1,21.5 \pm 0.3,25 \pm 0.3$ and $28 \pm 0.3^{\circ} \mathrm{C}$ and $18 \mathrm{~L}: 6 \mathrm{D}$ photoperiod. Egg hatch was recorded daily at 08:00, 14:00 and 20:00 $\mathrm{h}$. Since the development time of eggs in a batch is synchronised 
ApPendix. Calculation of standard deviation of lower devel-

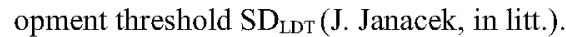

The $\mathrm{SD}_{\mathrm{LDT}}$ was calculated assuming a linear relationship devel-
opment rate $(\mathrm{R})$ and temperature $(\mathrm{t})$
$\mathrm{R}=\mathrm{a} * \mathrm{t}+\mathrm{b}$
measured over $\mathrm{n}$ experimental temperatures.
Then:
$\mathrm{SD}_{\mathrm{LDT}}=\left[\left(\mathrm{A} \times \mathrm{a}^{-2}\right)+\left(2 \times \mathrm{B} \times \mathrm{b} \times \mathrm{a}^{-3}\right)+\left(\mathrm{C} \times \mathrm{b}^{2} \times \mathrm{a}^{-4}\right)\right]^{1 / 2}$
where
$\mathrm{A}=\mathrm{D} \times \mathrm{E} \times \Sigma \mathrm{t}^{2}$
$\mathrm{~B}=\mathrm{D} \times \mathrm{E} \times \Sigma \mathrm{t}$
$\mathrm{C}=\mathrm{D} \times \mathrm{E} \times \mathrm{n}$
where
$\mathrm{D}=\left[\mathrm{n} \times \Sigma \mathrm{t}^{2}-(\Sigma \mathrm{t})^{2}\right]^{-1}$
$\mathrm{E}=\left[\Sigma \mathrm{R}^{2}-\mathrm{b} \times \Sigma \mathrm{R}-\mathrm{a} \times \Sigma(\mathrm{t} \times \mathrm{R})\right] \times(\mathrm{n}-2)$

(eggs hatched within 1-3 h) eclosion was recorded for individual batches. Neonate larvae were counted and egg mortality recorded for small batches (10-40 eggs), which were easy to count. Average mortality was determined using 15-20 batches at each temperature.

Larval development. Egg batches were removed from the stock culture every 12 hours and maintained at $25^{\circ} \mathrm{C}$ and a natural photoperiod (at the time of experiment c. $16.5 \mathrm{~L}: 7.5 \mathrm{D}$ ) until they hatched. Five to seven batches were placed in a $10 \mathrm{~cm}$ diameter Petri dish and a piece of fresh leaf was added daily to maintain air humidity. Neonate larvae were removed every six hours. The larvae were placed individually in $18 \times 85 \mathrm{~mm}$ glass tubes covered with a plastic lid and fed with fresh leaves, which were replaced at two to three day intervals. The tubes, 50 at each temperature, were kept at $18 \pm 0.1,21.5 \pm 0.3,25 \pm 0.3$ and $28 \pm 0.3^{\circ} \mathrm{C}$ and $18 \mathrm{~L}: 6 \mathrm{D}$ photoperiod. After completing larval development, the pre-pupae, attached to the substrate by the distal part of their abdomens, were placed in new tubes of the same size containing a piece of compressed cotton wool, which was moistened with six drops of tap water. The larval-larval ecdyses were not recorded, larval-pupal ecdyses were recorded at 08:00 and 20:00 $\mathrm{h}$. The length of the larval stage and larval mortality were measured from egg hatch to the larval-pupal ecdysis.

Pupal development. The pupae were left in their tubes, and kept at the same temperature and photoperiod as the larvae. The cotton wool was moistened every three days with five droplets of water. Adult ecdyses were recorded every 12 hours. Pupae were considered "dead" if an adult did not emerge within 14 days of the last to emerge at that temperature.

Oviposition and adult longevity. The adult performance of individuals reared from egg to adult at $25^{\circ} \mathrm{C}$ and a natural photoperiod was observed. The larvae (150 individuals) were reared as above. The adults were sexed three days after emergence, when the abdomens of females began to swell. One male and one female adult were then placed into a $18 \times 140 \mathrm{~mm}$ glass tube sealed with plastic lid and supplied with a piece of fresh leaf. The tubes were kept at the same temperatures and photoperiod as the earlier stages, 11-14 tubes per treatment. The leaves were replaced, eggs counted and removed, and mortality checked every two to three days until the death of the last individual in the cohort.

Thermal constants. The lower development threshold, the temperature below which development ceases, and the sum of effective temperatures, the quantity of heat required to complete a developmental stage, were calculated from a linear regression of development rate $\mathrm{R}$, the reciprocal of development time, on temperature $t$ as

\section{$\mathrm{R}=\mathrm{at}+\mathrm{b}$}

where $\mathrm{a}$ and $\mathrm{b}$ are regression coefficients. The lower development threshold was calculated as $-b / a$ and the sum of effective temperatures as 1/a. Standard errors of lower development threshold were calculated according to J. Janacek (in litt.). (Appendix).

Rate isomorphy. Rate isomorphy implies no change in the proportion of time spent in a particular developmental stage with respect to change in temperature. The ratios of the times spent in each developmental stage at constant temperatures of $18,21.5,25$ and $28^{\circ} \mathrm{C}$ were recalculated from data on the duration of development as the time spent in a particular stage divided by the total pre-imaginal development $($ egg + larva + pupa). Rate isomorphy was tested by analysis of covariance using the arcsin $\sqrt{\text { proportion }}$ of the time spent in each stage as a response variable and temperature as a covariate. The proportion of time spent in each developmental stage was considered isomorphic if there was no relationship between the proportion and temperature. A significant $(\mathrm{p}<0.05)$ increase or decrease in the proportion (non-zero slope of regression line on temperature) violated the assumption of rate isomorphy. The results for the individual stages of a population of a species are not statistically independent as a change in the proportion of the time spent in one stage changes the other proportions. Therefore, the data were evaluated as isomorphic only if the proportion of time spent in all stages appeared isomorphic. Temperature was first regressed with a different intercept and a different slope on each stage, and the significance was then evaluated by removing all the slopes by a deletion test simultaneously.

Life tables. For each female oviposition and mortality were checked at two or three day intervals. Daily oviposition was calculated by dividing the total number of eggs laid over an interval by its length (number of days). Time of death was the beginning of the age interval in which the animal died. Life tables were then compiled and life history parameters calculated according to Andrewartha \& Birch (1954). Age of female (pivotal age $\mathrm{x}$, days) was calculated by summing the average egg, larval and pupal development times, and adult age. Number of female births $m_{x}$ (number of eggs destined to become females) was calculated as the average number of eggs laid by a female of age $x$ divided by two. Survival probability $1_{x}$ (proportion of females alive at the beginning of $x$-th age interval) was calculated by multiplying the survival probability of the egg, larval, and pupal stages and the probability of survival (to age $\mathrm{x}$ ) of a female. Age specific fecundity was calculated as $1_{x} m_{x}$, net reproduction rate $R_{0}$ (multiplication per generation) as $\Sigma l_{x} m_{x}$, and mean generation time $\mathrm{T}$ (mean time from birth of parents to birth of offspring) as $1_{x} m_{x} x / l_{x} m_{x}$. Intrinsic rate of population increase $r_{m}$ was calculated as $r_{m}=\ln R_{0} / T$.

Voltinism. The temperature sum available for $G$. viridula development was calculated as the differences between actual temperatures in the open and the species lower development threshold summed over the growing season. Average monthly temperatures were used to calculate the number of generations at Praha-Ruzyne $\left(50^{\circ} \mathrm{N}, 14^{\circ} \mathrm{E}\right.$, altitude $\left.350 \mathrm{~m}\right)$. The 20 year average monthly temperatures were $7.8,12.7,16.3,17.6,16.8$, 13.2 and $8.2^{\circ} \mathrm{C}$ in April to October, respectively. Differences between average monthly temperatures and the development threshold were multiplied by the number of days in each month. To calculate the number of generations the sum of monthly totals was divided by the mean generation time $T_{0}$ expressed in day degrees above the lower development threshold. 
TABLE 1. The effect of temperature on development of eggs, larvae and pupae of Gastrophysa viridula. D - mean duration (days $\pm \mathrm{SE}$ ) of development of a stage; $\mathrm{P}$ - proportion of total development spent in a stage.

\begin{tabular}{|c|c|c|c|c|c|c|c|}
\hline \multirow{2}{*}{$\begin{array}{l}\text { Tem- } \\
\text { perature } \\
{ }^{\circ} \mathbf{C}\end{array}$} & \multicolumn{2}{|c|}{ Egg } & \multicolumn{2}{|c|}{ Larva } & \multicolumn{2}{|c|}{ Pupa } & \multirow{2}{*}{$\begin{array}{c}\text { Total } \\
\text { D }\end{array}$} \\
\hline & D & $\mathbf{P}$ & D & $\mathrm{P}$ & D & $\mathbf{P}$ & \\
\hline 18 & $\begin{array}{c}6.6 \pm 0.1 \\
(24 *)\end{array}$ & 0.23 & $\begin{array}{c}15.4 \pm 0.1 \\
\quad(46)\end{array}$ & 0.55 & $\begin{array}{c}6.2+0.1 \\
(46)\end{array}$ & 0.22 & 28.2 \\
\hline 18 & $\begin{array}{c}5.2 \pm 0.1 \\
\left(40^{*}\right)\end{array}$ & 0.24 & $\begin{array}{c}11.5 \pm 0.1 \\
(36)\end{array}$ & 0.53 & $\begin{array}{c}4.9 \pm 0.1 \\
(27)\end{array}$ & 0.23 & 21.6 \\
\hline 25 & $\begin{array}{c}3.7 \pm 0.0 \\
\left(37^{*}\right)\end{array}$ & 0.23 & $\begin{array}{c}8.5 \pm 0.1 \\
(34)\end{array}$ & 0.53 & $\begin{array}{c}3.9 \pm 0.1 \\
(26)\end{array}$ & 0.24 & 16.1 \\
\hline 28 & $\begin{array}{c}3.4 \pm 0.1 \\
\left(37^{*}\right)\end{array}$ & 0.23 & $\begin{array}{c}8.2 \pm 0.1 \\
(33)\end{array}$ & 0.55 & $\begin{array}{c}3.4 \pm 0.1 \\
(19)\end{array}$ & 0.23 & 15.0 \\
\hline
\end{tabular}

Data processing. The differences in mortality between temperatures within development stages were tested by the chisquare test, with null hypothesis assuming equal mortality at each temperature. The differences between lower development thresholds calculated for particular stages were tested by t-test, after testing for homogeneity of their variances by F-test (Reisenauer, 1965). The variation in adult longevity was also tested by two-way ANOVA with duration of adult life as the response variable and gender and temperature as factors. The variation between temperatures in duration of pre-oviposition, oviposition and post-oviposition period was tested in a one-way ANOVA, with individual duration of the period as the response variable and temperature as a factor. The significance of differences between temperatures in duration of pre-oviposition, oviposition and post-oviposition periods and total male and female longevity were tested by a post-hoc LSD test. All ANOVA tests were performed using STATISTICA for Windows (StatSoft, 1994).

\section{RESULTS}

Pre-adult development. The duration of development of each of the stages of $G$. viridula decreased with increasing temperature (Table 1). Mortality varied with development stage and temperature over the range studied (Table 2). Egg mortality differed significantly (chi-square $=10.8, \mathrm{p}<0.01$ ) but there was no consistent trend with increasing temperature. Larval (chi-square $=7.9, \mathrm{p}<$ 0.01 ) and pupal (chi-square $=12.5, \mathrm{p}<0.01$ ) mortalities increased with temperature. In consequence, the probability of survival to the adult stage decreased with temperature. The proportion of individuals surviving to

TABLE 3. The thermal constants, lower development threshold $\mathrm{LDT} \pm \mathrm{SE}\left({ }^{\circ} \mathrm{C}\right)$ and sum of effective temperatures SET (day degrees), calculated from parameters of the linear regression ( $\mathrm{a}, \mathrm{b})$ of development rate on temperature. The values for the lower development threshold are not significantly different $\left(\mathrm{p}_{\mathrm{t}}>0.05\right)$.

\begin{tabular}{lcccr}
\hline & $\mathrm{a}$ & $\mathrm{b}$ & $\mathrm{LDT}$ & $\mathrm{SET}$ \\
\hline Egg & 0.0152 & -0.1234 & $8.1 \pm 1.9$ & 66.0 \\
Larva & 0.0061 & -0.0425 & $7.0 \pm 2.6$ & 164.8 \\
Pupa & 0.0135 & -0.0823 & $6.1 \pm 0.5$ & 74.3 \\
Total & 0.0033 & -0.0233 & $7.1 \pm 1.9$ & 304.6 \\
\hline
\end{tabular}

TABLE 2. Percent mortality of $G$. viridula during each developmental stage at four temperatures. Brackets denote the initial number of individuals. The mortality differed significantly between temperatures $\left(p_{\text {chi-square }}<0.01\right.$ ) in all developmental stages.

\begin{tabular}{lccc}
\hline Temperature & \multicolumn{3}{c}{$\%$ mortality } \\
\cline { 2 - 4 }${ }^{\circ} \mathrm{C}$ & Egg & Larva & Pupa \\
\hline 18 & 19.0 & 8.0 & 0.0 \\
& $(578)$ & $(50)$ & $(46)$ \\
21.5 & 29.1 & 22.9 & 24.3 \\
& $(351)$ & $(48)$ & $(37)$ \\
25 & 21.2 & 30.6 & 23.5 \\
& $(387)$ & $(49)$ & $(34)$ \\
28 & 24.7 & 32.7 & 30.3 \\
& $(539)$ & $(49)$ & $(33)$ \\
Average & 23.0 & 23.5 & 18.0 \\
& $(1855)$ & $(196)$ & $(150)$ \\
\hline
\end{tabular}

adulthood were $0.744,0.422,0.415$ and 0.361 at $18,21.5$, 25 and $28^{\circ} \mathrm{C}$, respectively. Thermal constants varied between particular development stages (Table 3). The estimates of lower development threshold for development stages were between $6.1-8.1^{\circ} \mathrm{C}$ and for the total development it was $7.1^{\circ} \mathrm{C}$. The differences between the lower development thresholds for particular stages were not significant $\left(\mathrm{p}_{\mathrm{t}}>0.05\right)$. Thermal requirements were highest for the larval (sum of effective temperatures = 164.8 day degrees) followed by the pupal (74.3 day degrees) and egg stages (66.0 day degrees). Total development of $G$. viridula required 304.6 day degrees. Tests for rate isomorphy showed there was no significant change in the average proportion of time spent in the egg, larva and pupal stages at different constant temperatures (deletion test of regression slopes of the proportions on temperature: $\mathrm{F}_{3,9}=0.65, \mathrm{p}=0.603$ ).

Adult life. Reproduction and adult life span were significantly influenced by temperature. Average longevity (Table 4) decreased with temperature $\left(\mathrm{F}_{3,91}=8.375, \mathrm{p}=\right.$ 5.64E-5) and was greater in males than females $\left(\mathrm{F}_{1,91}=\right.$ $15.219, \mathrm{p}=1.83 \mathrm{E}-4)$. The interaction between sex and temperature was not significant $\left(\mathrm{F}_{3,91}=0.333, \mathrm{p}=0.801\right)$. The pre-oviposition period $\left(\mathrm{F}_{3,45}=6.874, \mathrm{p}=6.56 \mathrm{E}-4\right)$ and oviposition period $\left(\mathrm{F}_{3,45}=4.606, \mathrm{p}=6.79 \mathrm{E}-3\right)$ also decreased with temperature. The variation in postoviposition period $\left(\mathrm{F}_{3,44}=2.725, \mathrm{p}=5.55 \mathrm{E}-2\right)$ was not significant although its duration was about twice as long at $18^{\circ} \mathrm{C}$ as at $21.5-28^{\circ} \mathrm{C}$ (Table 4). The rate of oviposition decreased with female age (Fig. 1). The total number of eggs laid, $423 \pm 65,475 \pm 71,344 \pm 33$ and $413 \pm 65$ at $18,21.5,25$ and $28^{\circ} \mathrm{C}$, respectively, did not differ significantly $\left(\mathrm{F}_{3,45}=0.819, \mathrm{p}=0.490\right)$. The net reproduction rate $R_{0}$ and mean generation time $T$ decreased, and the intrinsic rate of population increase $r_{m}$ increased with temperature (Table 5).

\section{DISCUSSION}

Thermal constants of development. This study indicated the linear change of development and reproduction 
TABLE 4. Adult longevity (days $\pm \mathrm{SE}$ ) of female and male G. viridula, and duration of pre-oviposition, oviposition and postoviposition periods (days $\pm \mathrm{SE}$ ). For each period the values accompanied by the same letter are not significantly different at $\mathrm{p}<$ 0.05 .

\begin{tabular}{|c|c|c|c|c|c|c|c|}
\hline \multirow{2}{*}{$\begin{array}{l}\text { Temperature } \\
{ }^{\circ} \mathrm{C}\end{array}$} & \multicolumn{5}{|c|}{ Female } & \multicolumn{2}{|c|}{ Male } \\
\hline & $\mathrm{n}$ & pre-oviposition & oviposition & post-oviposition & total & $\mathrm{n}$ & total \\
\hline 18 & 14 & $7.7 \pm 0.7 \mathrm{a}$ & $19.4 \pm 2.8 \mathrm{a}$ & $6.3 \pm 1.7 \mathrm{a}$ & $33.4 \pm 2.9 \mathrm{a}$ & 13 & $48.0 \pm 7.1 \mathrm{a}$ \\
\hline 21.5 & 11 & $7.6 \pm 0.3 \mathrm{a}$ & $15.9 \pm 3.2 \mathrm{ab}$ & $2.3 \pm 0.7 b$ & $23.2 \pm 2.1 \mathrm{~b}$ & 11 & $43.0 \pm 7.0 \mathrm{a}$ \\
\hline 25 & 13 & $5.2 \pm 0.4 b$ & $9.5 \pm 0.6 \mathrm{~b}$ & $2.5 \pm 0.5 b$ & $17.2 \pm 0.8 b$ & 15 & $27.9 \pm 3.5 b$ \\
\hline 28 & 11 & $5.3 \pm 0.3 b$ & $9.5 \pm 1.3 b$ & $3.4 \pm 0.6 \mathrm{ab}$ & $18.1 \pm 1.2 b$ & 11 & $28.1 \pm 2.5 b$ \\
\hline
\end{tabular}

rate across a range of temperatures that $G$. viridula usually experiences during its development and reproduction in the field. The lower development thresholds for particular development stages were calculated by extrapolation of the data and are thus likely to be biased. However, the magnitude of standard deviation of lower development threshold revealed that our estimates are sufficiently precise. Moreover, the lack of precision in the lower development threshold and sum of effective temperatures is not important for the forecasting of development duration (Jarosik et al., 2002). Because the development threshold and temperature sum of a stage are intercorrelated an error in lower development threshold is accompanied by a corresponding error in sum of effective temperatures. When calculating the length of development of a stage, the error in temperature sum compensates for the poor estimate of development threshold.

In many species the development rate at low temperatures, as one approaches the lower development threshold, positively departs from values predicted by the linear relationship (Charnov \& Gillooly, 2003). We might thus expect the non-linear development rate vs. temperature relationship also in G. viridula. However, the nonlinearity might be amplified by differential mortality. Immature individuals of many insect species kept at constant temperatures a few degrees above the lower development threshold will not develop to the next stage but die. The mortality may be high even at $5-10^{\circ} \mathrm{C}$ above the lower development threshold. For instance, in larvae of Chironomus crassicaudatus Malloch (lower development threshold c. $6^{\circ} \mathrm{C}$ ) mortality was 95 percent at $12.5^{\circ} \mathrm{C}$ and 75 per cent at $15^{\circ} \mathrm{C}$. In the temperature range between $17.5-32.5^{\circ} \mathrm{C}$ the mortality was only $10-23$ percent (Frouz et. al., 2002). The development rate apparently increased at low temperatures because individuals with the fastest development complete their development early while the rest succumb to adverse conditions, the more so if their development is prolonged (Jarosik et al., 2002).
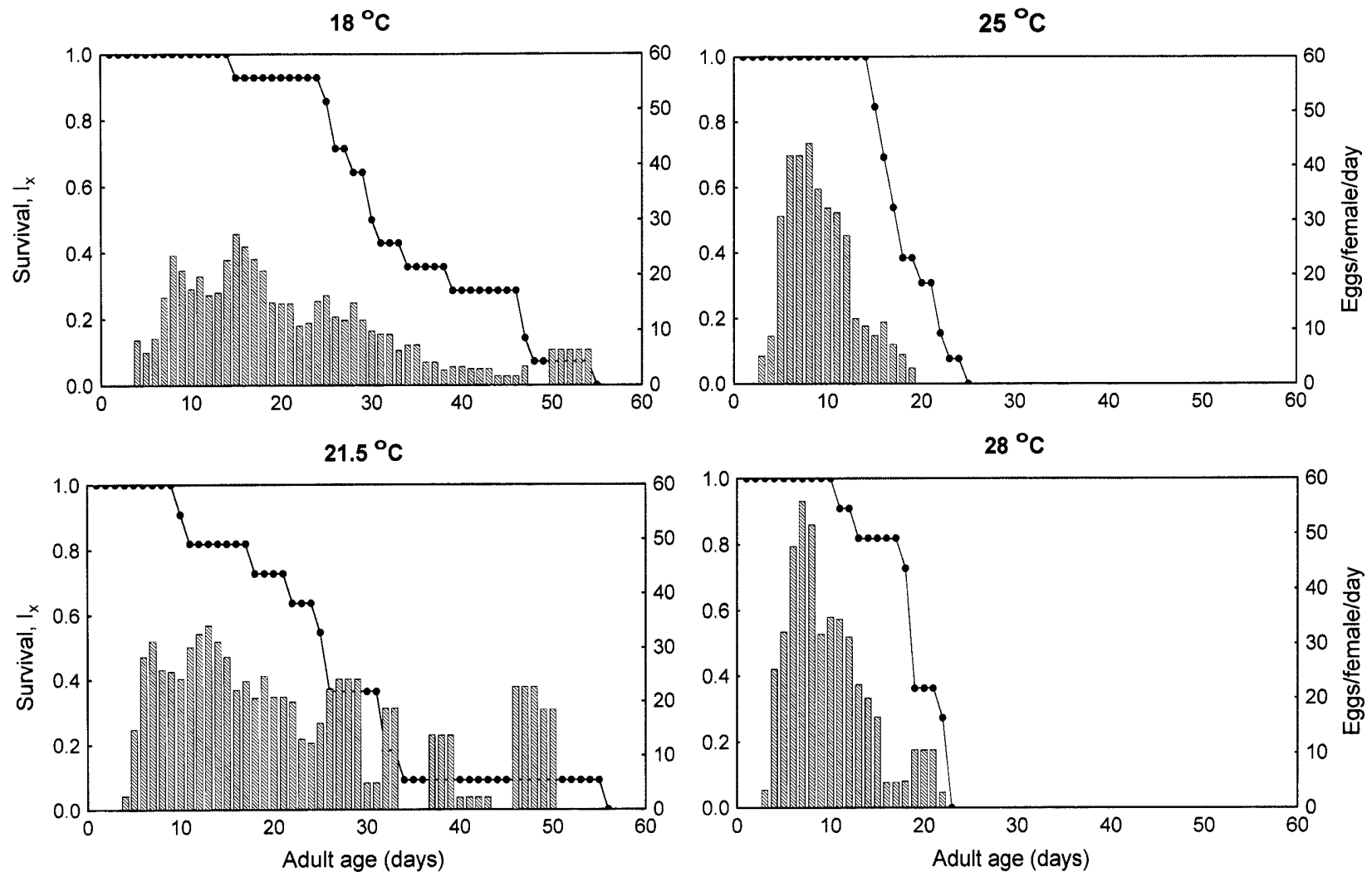

Fig. 1. Average daily number of eggs laid per female G. viridula (bars, right ordinate) and proportion of surviving females (line, left ordinate) in relation to female age (days from adult eclosion) at four constant temperatures. 
TABLE 5. Net reproduction rate $\left(\mathrm{R}_{0}\right)$, generation time $(T)$ and intrinsic rate of population increase $\left(\mathrm{r}_{\mathrm{m}}\right)$ of Gastrophysa viridula populations at different temperatures. $\mathrm{n}$ - number of females tested.

\begin{tabular}{lcrcc}
\hline Temperature $\left({ }^{\circ} \mathrm{C}\right)$ & $\mathrm{n}$ & \multicolumn{1}{c}{$\mathrm{R}_{\mathrm{o}}$} & $\mathrm{T}$ & $\mathrm{r}_{\mathrm{m}}$ \\
\hline 18 & 14 & 157.3 & 45.5 & 0.111 \\
21.5 & 11 & 100.3 & 37.2 & 0.124 \\
25 & 13 & 71.3 & 25.0 & 0.171 \\
28 & 11 & 74.5 & 24.1 & 0.179 \\
\hline
\end{tabular}

Rate isomorphy. The assumption of "rate isomorphy" is that, under different temperatures, a developmental stage takes a constant proportion of the total development time. In this case the regression lines of development rate on temperature for particular stages all intersect the abscissa at one point, the lower development threshold. That is, it is the same for all development stages. The published experimental data (reviewed by Honek \& Kocourek, 1990; Honek, 1996; Kiritani, 1997), as well as results of our study, revealed wide spread intra-specific variation in the lower development threshold for particular development stages. If the development is isomorphic this variation is only apparent, i.e. caused by imprecise observation of development times. Jarosik et al. (2002) proposed a statistical method of testing the data for rate isomorphy and demonstrate the existence of rate isomorphy for a large number of species. Also in $G$. viridula the asumption of isomorphy was not rejected although calculated temperature thresholds are different for particular stages. The "isomorphic" response to temperature implies an identical lower development threshold for all the pre-adult development stages.

The results thus did not contradict the prediction (Jarosik et al., 2002) of the wide spread occurrence of "rate isomorphy". However, its actual distribution among insect taxa should be studied, with regard to variation in life-cycles (Danks, 1987) and temperature reactions including acclimation (Precht et al., 1973). By contrast, thermal requirements for completing a particular development stage are plastic and can vary according food quality (Honek et al., 2002) and humidity (Hagstrum \& Milliken, 1988). Differences in food quality may cause some variation in the duration of development of $G$. viridula under natural conditions, in parallel with ageing of leaves of its host plant, $R$. obtusifolius.

Biocontrol of dock. The magnitude of the biocontrol effects of $G$. viridula depends on its abundance and the duration of herbivory, which both increase with the number of generations. The studies in western Europe reported three (Smith \& Whittaker, 1980a) or four (Swatonek, 1972) generations per year. Smith and Whittaker (1980a) demonstrated that the number of generations per year increased as a consequence of cutting followed by regrowth of physiologically young leaves. However, the abundance of natural enemies also increased during the course of the season and negatively affected the abundance of the second and third generations. The maximum number of generations that $G$. viridula can complete is limited by temperature and may be calculated using the results of this study, the lower development threshold of $7.1^{\circ} \mathrm{C}$, average temperature sum accumulated over the vegetation period at Praha-Ruzyně of 1314 day degrees and the mean generation time of $496 \pm 16$ day degrees calculated from Table 5 as the mean of $\mathrm{T}_{0}$ expressed in day degrees. $G$. viridula thus can complete 2.4 generations per year. In central European conditions the third generation is probably incomplete and consists of a few early born offspring of the second generation. Temperature thus limits the effect of late summer herbivory, which might significantly reduce their biocontrol effect on Rumex spp., particularly of newly established seedlings.

ACKNOWLEDGEMENTS. The authors wish to thank A.F.G. Dixon (Norwich, UK), P.E. Hatcher (Reading, UK) and S. Carroll (Davis, USA) for helpful comments on the manuscript, and L. Kreslová and $\mathrm{H}$. Uhlíŕová for excellent technical assistance. The work was funded by a grant from the Ministry of Agriculture of the Czech Republic no. M 01-01-01 to ZM and M 0101-03 to A.H. V.J. was supported by grant no. J13/98113100004 from the Ministry of Education of the Czech Republic.

\section{REFERENCES}

Andrewartha H.G. \& Birch L.C. 1954: The Distribution and Abundance of Animals. The Chicago, University of Chicago Press, $782 \mathrm{pp}$.

Barbattini R., Zandigiacomo P. \& Parmegiant P. 1986: Indagine preliminare sui fitofagi di Rumex obtusifolius L. e Rumex crispus L. in vigneti del Friuli. Redia 69: 131-142.

Bassyouny A.M. \& MaAReg M.F. 1992: Biology and life tables of the sugarbeet beetle Cassida vittata Vill. (Coleoptera: Chrysomelidae). Ann. Agric. Sci. 30: 571-580.

Bhumannavar B.S., Balasubramantan C. \& Ramani S. 1998: Life table of the Mexican beetle, Zygogramma bicolorata Pallister on parthenium and sunflower. J. Biol. Contr. 12: 101-106.

Bulcke R., De Bruyne P., Van Himme M. \& Callens D. 1994 Response of weed flora and crop yield to yearly repeated herbicide applications in continuous maize. Med. Fac. Landbouw. Toegepaste Biol. Wet. Univ. Gent 59: 1265-1275.

Charnov E.L. \& Gillooly J.F. 2003: Thermal time: body size, food quality and the $10^{\circ} \mathrm{C}$ rule. Evol. Ecol. Res. 5: 43-51.

CHevin H. 1968: Influence de la plante-hôte sur le cycle évolutif de deux éspéces de Gastrophysa. Bull. Soc. Entomol. Fr. 73: $128-140$.

Cottam D.A., Whittaker J.B. \& Malloch A.J.C. 1986: The effect of chrysomelid beetle grazing and plant competition on the growth of Rumex obtusifolius. Oecologia 70: 452-456.

Danks H.V. 1987: Insect Dormancy: an Ecological Perspective. Ottawa, Biological Survey of Canada, $439 \mathrm{pp}$.

De Pecchioni M.T.D., Cabrera N., Laguzzi S.M. \& Novara C.R. 2000: Aspectos morfologicos y poblacionales de Diabrotica speciosa speciosa (Germar) (Coleoptera: Chrysomelidae) en condiciones de laboratorio. Ann. Soc. Entomol. Brasil 29: 285-294.

Engel H. 1956: Beiträge zur Lebensweise des Ampferblattkäfers (Gastrophysa viridula Deg.). Z. Angew. Entomol. 38: 323-354.

Frouz J., Ali A. \& Lobinsike R.J. 2002: Influence of temperature on developmental rate, wing length, and larval head capsule size of pestiferous midge Chironomus crassicaudatus (Diptera: Chironomidae). J. Econ. Entomol. 95: 699-705. 
Gulle C.T. 1984: Damage to rhubarb (Rheum rhaponticum L.) and Virginia creeper (Parthenocissus quinquefolia (L.) Planch.) by dock beetle (Gastrophysa viridula Degeer). Plant Path. 33: 269-270.

Hagstrum D.W. \& Milliken G.A. 1988: Quantitative analysis of temperature, moisture and diet factors affecting insect development. Ann. Entomol. Soc. Am. 81: 539-546.

HanN P. \& KROMP B. 2001: Ampferregulierung mittels Ampferblattkäfer: erste Ergebnisse. In: Anonymous: 7. Alpenländisches Expertenforum. Bundesanstalt für alpenländische Landwirtschaft Gumpenstein, Irdning, pp. 63-67.

HATCHER P.E. 1996: The effect of insect-fungus interactions on the autumn growth and over-wintering of Rumex crispus and R. obtusifolius seedlings. J. Ecol. 84: 101-109.

Hatcher P.E., Paul N.D., Ayres P.G. \& Whittaker J.B. 1994a: The effect of a foliar disease (rust) on the development of Gastrophysa viridula (Coleoptera: Chrysomelidae). Ecol Entomol. 19: 349-360.

Hatcher P.E., Paul N.D., Ayres P.G. \& Whittaker J.B. 1994b: Interactions between Rumex spp., herbivores and a rust fungus: Gastrophysa viridula grazing reduces subsequent infection by Uromyces rumicis. Funct. Ecol. 8: 265-272.

Hatcher P.E., Paul N.D., Ayres P.G. \& Whittaker J.B. 1997: Added soil nitrogen does not allow Rumex obtusifolius to escape the effects of insect-fungus interactions. J. Appl. Ecol. 34: $88-100$.

HoneK A. 1996: The relationship between thermal constants for insect development: a verification. Acta Soc. Zool. Bohem. 60: 115-152.

Honek A. \& Kocourek F. 1990: Temperature and development time in insects: a general relationship between thermal constants. Zool. Jb. Syst. 117: 401-439.

HoneK A., Jarosik V., Martinkova Z. \& Novak I. 2002: Food induced variation of thermal constants of development and growth of Autographa gamma (Lepidoptera: Noctuidae) larvae. Eur. J. Entomol. 99: 241-252.

Jarosik V., HoneK A. \& Dixon A.F.G. 2002: Rate isomorphy in insects and mites. Am. Nat. 160: 497-510.
KIRITANI K. 1997: The low development threshold temperature and thermal constants in insects, mites and nematodes in Japan. Misc. Publ. Nat. Inst. Agro-Environ. Sci. 21: 1-72.

Kovalenkov V.G. \& Stolyarov V.D. 2000: Particularities of the phytosanitary state of agrosystems of Stavropole. Zashch. Karant. Rast. 2000: 13-14. [in Russian, English summ.]

Neubauter S., Kuimes K. \& Stary F. 1979: The knotweed leaf beetle - Gastroidea viridula Deg. (Coleoptera) - a pest of tangutian palmate rhubarb. Sb. UVTIZ Ochrana Rostlin 15: 305-308. [in Czech, English summ.]

Precht H., Christophersen J., Hensel H. \& Larcher W. 1973: Temperature and Life. Berlin, Springer-Verlag, $779 \mathrm{pp}$.

REISENAUER R. 1965: Methods of Mathematical Statistics. Praha, Statni Technicke Nakladatelstvi, 208 pp. [in Czech]

RenNeR K. 1970: Zur Fortpflanzungsbiologie und Embryonalentwicklung von Gastroidea viridula Deg. (Col.: Chrysomelidae). Zool. Anz. 185: 274-283.

SMith R.W. \& WhitTaKer J.B. 1980a: Factors affecting Gastrophysa viridula populations (Coleoptera: Chrysomelidae) in different habitats. J. Anim. Ecol. 49: 537-548.

SMith R.W. \& Whittaker J.B. 1980b: The influence of habitat type on the population dynamics of Gastrophysa viridula DeGeer (Coleoptera: Chrysomelidae). J. Anim. Ecol. 49: 225-236.

StatSoft 1994: Statistica for Windows (Volume I): General Conventions and Statistics I. Tulsa, StatSoft Inc.

Swatoner F. 1972: Ein Beitrag zur Biologie des Ampferblattkäfers (Gastroidea viridula Deg.). Anz. Schädlingsk. Pflschutz 45: 116-119.

WAN F.H. \& WANG R. 1990: An experimental population life table of Zygogramma suturalis (Col.: Chrysomelidae), a potential biological control agent of Ambrosia artemisifolia. Chin. J. Biol. Contr. 6: 64-67.

ZIMMERMANN K. \& TOPP W. 1991: Anpassungserscheinungen von Insekten an Neophyten der Gattung Reynoutria (Polygonaceae) in Zentraleuropa. Zool. Jb. Syst. 118: 377-390.

Received January 6, 2003; revised April 19, 2003; accepted May 13, 2003 